\title{
Simulation Model to Reduce the Traffic Jams with a Stochastic Program
}

\author{
M. ALI MUSRI S \\ Universitas Pembinaan Masyarakat Indonesia (UPMI) \\ J1. Teladan No.15, Teladan Barat, Medan \\ INDONESIA \\ SITI FATIMAH \\ Universitas Potensi Utama \\ Jl. KL Yos Sudarso Km 6,5 No 3A, Tanjung Mulia, Medan \\ INDONESIA \\ SAIFUL ANWAR MATONDANG \\ Universitas Islam Sumatera Utara \\ Jl. Sisingamangaraja No.Kelurahan, Teladan Barat, Medan \\ INDONESIA
}

\begin{abstract}
Traffic congestion needs a simulation model to reduce its effects on traffics jams and pollution. The traffic cessation caused by the large number of vehicles exceeding the capacity of the road users. This study applied a stochastic program to the traffic congestion; it causes most of the working hours to be spent on roads that indirectly place a negative impact on economic growth. It also causes serious air pollution that will worsen the overall environmental condition. Data obtained show the factors causing traffic congestion in the city of Medan and with approach the stochastic program model used to solve this problem. Data indicated that there are four factors causing traffic congestion in Medan, which are non-growth of road, economic growth, population growth, and increase of motor vehicle.Population factor; the existence of good population growth caused by natural and migration growth. It concludes that the traffic jams are due to the socio-economic factors; namely the development of community business activities. Also socio-cultural factors; the existence of changes in the pattern of life and public order due to outside influences, communication, and information systems.
\end{abstract}

Key-Words: Stochastic program, traffic congestion, population growth, road length

Received: March 22, 2021. Revised: November 7, 2021. Accepted: December 5, 2021. Published: January 7, 2022.

\section{Introduction}

Traffic Jam is one of the important issues in public spaces, it makes the congestion the number of vehicles exceeding the capacity of the road users. The negative impact of traffic congestion also causes most of the working hours to be spent on roads that indirectly gives a negative impact on economic growth. It also causes air pollution that will worsen the overall environmental condition. Therefore, it is hoped that by reducing traffic congestion, the city can play a very important role in people's lives by ensuring a healthy environment that is free from pollution [1].
Traffic congestion continues to be a major problem in cities around the world, especially in developing countries which result in major delays, increased fuel wastage and monetary losses. Due to the poor road network, the general result of many developing countries is the presence of small, critical areas that are common to congestion with poor traffic management around this area is potentially resulting in long traffic congestion. Weak traffic management is the main reason for worldwide traffic congestion [2]. For example, traffic congestion in Medan City is getting more and more chaotic. The absence of a clear spatial layout concept for the city of Medan as along-term transportation network plan results from the poor development of Medan City. 
Two main categories cause traffic congestion: (a) micro-level factors (eg. relating to on-road traffic) and (b) macro-level factors associated with overall demand for road users. Traffic congestion is triggered at the micro-level (eg. on the road) and driven at the macro level by factors that contribute to the occurrence of traffic congestion. Micro-level factors, for example, many people and goods want to move at the same time means too many vehicles for limited road space. Many trips may be delayed by irregular but frequent events, such as accidents, vehicle damage, false traffic signals, special events such as mass social gatherings, political demonstrations, adverse weather conditions, etc., which are contributing to various traffic problems. On the other hand, macro-level factors such as land use, income levels, car ownership trends, infrastructure investment, regional economic dynamics, etc. can also cause congestion [3].

Traffic congestion arises when a highway approach system is concerned with vehicle capacity, resulting in many negative impacts from fuel disposal and increasing exhaust emissions. Several studies have modelled the situation in urban areas and the economic values associated with excessive fuel consumption and time wasted in traffic. While this is a considerable economic loss, there are several externals of unspecified congestion, including the public health impact of excess air pollutant emissions during the period of congestion [4].

\section{Method}

This research applied the Stochastic Program to make a simulation model to reduce the traffic jam in Medan Municipal of North Sumatra, Indonesia. Based on the incorporation of uncertainty into the constraints and objective function of a mathematical program would result in a stochastic program [8]. This Stochastic program was used as a form of a stochastic model that may reduce traffic congestion in Medan City. The Stochastic programming refers to a mathematical program that can be linear, mixed, nonlinear, but by displaying stochastic elements in the data. Many mathematical problems have been used to determine a feasible model of settlement when the problem arises uncertainty. Many optimization issues contain uncertainty [5]. Some cases of these problems contain a random process or some unknown information. The incorporation of this uncertainty into the constraints and objective functions of a mathematical program produces a stochastic program. It can therefore be stated that as:
1.In a deterministic math program, data (coefficients) are known (certain) numbers.

2.In the stochastic program, the data (coefficient) is an unknown number (uncertain) presented as an opportunity distribution.

Stochastic programs are proposed to replace deterministic models, where unknown coefficients and parameters are random [6]. The general term of Stochastic Program can be expressed as follows:

$\min f(x)=c^{T} x=\sum_{j=1}^{n} c_{j} x_{j}$

s.t

$A_{i}^{T} x=\sum_{j=1}^{n} a_{i j} x_{j} \geq b_{i}, i=1,2, \ldots, m$

$x_{j} \geq 0, j=1,2, \ldots, n$

Where $c_{j}, a_{i j}$, and are discreet random variables

( $x_{j i \text { is }}$ assumed to be deterministic) which its probability distribution is known.

\section{Problem Solution}

The result of the analysis shows that 4 factors dominate the cause of traffic congestion in Medan; lack of road area, economic growth, population growth, an increasing number of vehicles.

Thus, its relation to the stochastic program model:

$$
\begin{aligned}
& \min f(x)=c^{T} x=\sum_{j=1}^{n} c_{j} x_{j} \\
& \min f(x)=c^{T} x=\sum_{j=1}^{n} c_{j} x_{j}=c_{1} x_{1}+c_{2} x_{2}+c_{3} x_{3}+c_{4} x_{4}
\end{aligned}
$$


$A_{i}^{T} x=\sum_{j=1}^{n} a_{i j} x_{j} \geq b_{i}, i=1,2,3,4$

$x_{j} \geq 0, j=1,2,3,4$

Note :

$x_{1}=$ Lack of road area

$x_{2}=$ Economic growth

$x_{3}=$ Population growth

$x_{4}=$ Increasing number of vehicles

Then, for each factor coefficients are obtained as $c_{1}=0,67 ; c_{2}=0,78 ; c_{3}=0,86 ; c_{4}=0,73$. So that, the general form of a stochastic program can be written as:

$\min f(x)=c^{T} x=\sum_{j=1}^{n} c_{j} x_{j}=c_{1} x_{1}+c_{2} x_{2}+c_{3} x_{3}+c_{4} x_{4}$

$\min f(x)=c^{T} x=\sum_{j=1}^{n} c_{j} x_{j}=0,67 x_{1}+0,78 x_{2}+0,86 x_{3}+0$

$A_{i}^{T} x=\sum_{j=1}^{n} a_{i j} x_{j} \geq b_{i}, i=1,2,3,4 x_{j} \geq 0, j=1,2,3,4$

In this model, the listed constant value of 0.67 can be interpreted that the variable width of the road that does not grow $\left(x_{1}\right)$ positive effect on traffic congestion in the city of Medan. When the width of the road does not increase has increased by one unit, then the traffic jam in Medan City will also increase by 0.67 units.

In this model, the value of the listed constants is 0.78 . In this model, the listed constant value of 0.78 can be interpreted that the variable of economic growth $\left(x_{2}\right)$ has a positive effect on traffic congestion in Medan. As economic growth increases by one unit, traffic congestion in Medan would increase toward 0.78 unit. In this model, the listed constant value of 0.86 can be interpreted that the variable increase in population $\left(x_{3}\right)$ has a positive effect on traffic congestion in Medan. As the population grows by an increase of one unit, traffic congestion in Medan could reach 0.86 unit. In this model, the listed constant value of 0.73 can be interpreted that the variable increase in the number of motor vehicles $\left(x_{4}\right)$ positively affect the traffic congestion in the city of Medan. As the number of motor vehicles increases by one unit, traffic congestion in Medan will also increase by 0.73 units.

\subsection{The Solution to Traffic Congestion in Medan}

Several steps can be taken to solve the traffic congestion problem that must be formulated in a comprehensive plan. Here are some alternative solutions to reduce traffic congestion in Medan City, namely:

1. Increase the capacity

a) Widen the road

b) Transform the traffic circulation into a one-way street

c) Reduce the conflict in the cross-section by limiting a certain traffic flow

2. Reduce the number of private vehicles and encouraged to use of public transportation

3. Provide a place to people who want to sell things that can prevent them to sell on the ${ }^{4}$ side of the road

4. Prohibit vehicles to park on the side of the road

5. Restriction on the number of vehicles

6. Increase the load capacity

7. Implement appropriate and effective traffic management.

8. Provide better public transportation which is professionally managed

9. Partiality to public transportation

\subsection{Population Growth}

The population is an important element in economic activity as well as an effort to build an economy because the population provides manpower, experts, heads of companies of entrepreneurs in creating economic activities [7]. Based on that, the population of Medan citizen for 6 years is shown in table 1 below. 
Table 1. Population Density of Medan City by District 2010-2016

\begin{tabular}{|c|c|c|c|c|}
\hline No. & Districts & $\begin{array}{l}\text { Large } \\
\left(\mathbf{K m}^{2}\right)\end{array}$ & $\begin{array}{l}\text { Populati } \\
\text { on }\end{array}$ & $\begin{array}{c}\text { Populatio } \\
\text { n density } \\
\left(/ \mathbf{K m}^{2}\right)\end{array}$ \\
\hline 1. & $\begin{array}{c}\text { Medan } \\
\text { Tuntunga } \\
\mathrm{n}\end{array}$ & 20,68 & 84.775 & 4.099 \\
\hline 2. & $\begin{array}{l}\text { Medan } \\
\text { Johor }\end{array}$ & 14,58 & 130.414 & 8.945 \\
\hline 3. & $\begin{array}{l}\text { Medan } \\
\text { Amplas }\end{array}$ & 11,19 & 121.362 & 10.846 \\
\hline 4. & $\begin{array}{l}\text { Medan } \\
\text { Denai }\end{array}$ & 9,05 & 145.677 & 16.097 \\
\hline 5. & $\begin{array}{l}\text { Medan } \\
\text { Area }\end{array}$ & 5,52 & 98.955 & 17.927 \\
\hline 6. & $\begin{array}{l}\text { Medan } \\
\text { Kota }\end{array}$ & 5,27 & 74.406 & 14.119 \\
\hline 7. & $\begin{array}{l}\text { Medan } \\
\text { Maimun }\end{array}$ & 2,98 & 40.624 & 13.097 \\
\hline 8. & $\begin{array}{l}\text { Medan } \\
\text { Polonia } \\
\end{array}$ & 9,01 & 55.369 & 6.145 \\
\hline 9. & $\begin{array}{c}\text { Medan } \\
\text { Baru }\end{array}$ & 5,84 & 40.519 & 6.938 \\
\hline 10. & $\begin{array}{c}\text { Medan } \\
\text { Selayang }\end{array}$ & 12,81 & 104.454 & 8.154 \\
\hline 11. & $\begin{array}{c}\text { Medan } \\
\text { Sunggal }\end{array}$ & 15,44 & 115.687 & 7.493 \\
\hline 12. & $\begin{array}{c}\text { Medan } \\
\text { Helvetia }\end{array}$ & 13,16 & 149.806 & 11.383 \\
\hline 13. & $\begin{array}{l}\text { Medan } \\
\text { Petisah } \\
\end{array}$ & 6,82 & 63.33 & 9.097 \\
\hline 14. & $\begin{array}{c}\text { Medan } \\
\text { Barat }\end{array}$ & 5,33 & 72.620 & 13.625 \\
\hline 15. & $\begin{array}{c}\text { Medan } \\
\text { Timur }\end{array}$ & 7,76 & 111.369 & 14.352 \\
\hline 16. & $\begin{array}{l}\text { Medan } \\
\text { Perjuanga } \\
\text { n }\end{array}$ & 4,09 & 95.790 & 23.421 \\
\hline
\end{tabular}

\begin{tabular}{|c|c|c|c|c|}
\hline 17. & $\begin{array}{l}\text { Medan } \\
\text { Tembung }\end{array}$ & 7,99 & 137.062 & 17.154 \\
\hline 18. & $\begin{array}{l}\text { Medan } \\
\text { Deli }\end{array}$ & 20,84 & 178.147 & 8.548 \\
\hline 19. & $\begin{array}{l}\text { Medan } \\
\text { Labuan }\end{array}$ & 36,67 & 116.357 & 3.625 \\
\hline 20. & $\begin{array}{l}\text { Medan } \\
\text { Marelan }\end{array}$ & 23,82 & 156.394 & 6.566 \\
\hline 21. & $\begin{array}{c}\text { Medan } \\
\text { Belawan }\end{array}$ & 26,25 & 98.020 & 3.734 \\
\hline \multicolumn{2}{|c|}{ Amount } & 265,10 & $\begin{array}{c}2.191 .14 \\
0\end{array}$ & $8.265,33$ \\
\hline
\end{tabular}

As the population keeps growing, the population density increases from 7,913people/ $\mathrm{Km}^{2}$ in 2010 to $8,265.33$ people $/ \mathrm{Km}^{2}$ pada in 2016 . The population density is relatively high, concerning where the available land area is relatively limited. This situation can certainly lead to an imbalance between the carrying capacity and the capacity of existing environments. The largest number of residents in Deli District is followed by Marelan and Helvetia. The lowest number of population is in Medan Baru, Medan Maimun and Medan Polonia. The highest population density is in Medan Perjuangan, Medan Area, and Medan Tembung. Meanwhile, the lowest population density is in Medan Labuhan Sub-district with 3,173 people $/ \mathrm{Km}^{2}$.

\subsection{City Growth}

According to Levy et al [4], a city is a residential area with a relatively large population, a highintensity workplace of the population and a place of public service. City growth refers to the notion of quantity, which in this case is indicated by the number of factors of production used by the city's economic system. The greater the production means an increasing demand.

City growth is a physical change of the city as a result of urban social development.

3 factors influence the growth of the city:

a. Population factor; the existence of good population growth caused by natural and migration growth

b. Socio-economic factors; namely the development of community business activities 
c. Socio-cultural factors; the existence of changes in the pattern of life and public order due to outside influences, communication, and information systems.

\subsection{The Approaching of a Stochastic Program to Prevent the Traffic Congestion in Medan}

Many management planning and operational issues that contain uncertainty are discussed and resolved via stochastic programs., for example, the problem of traffic congestion in Medan. This problem is related to knowing what factors are causing traffic jam in Medan (eg. population growth, economic growth, unevenness of shopping centres). So that the formulation of the problem is to determine the factors causing traffic congestion in Medan and how the stochastic program model used to solve traffic congestion problems.

\section{Conclusion}

Data interpretation gives two conclusions;

1. Simulation of Stochastic Program has four factors which cause the traffic congestion in Medan Municipal are: the lack of road area, economic growth, population growth, and the increase of private vehicles. Thus, to reduce the traffic congestion in Medan, the government needs to manage the road professionally and with full of responsibility. Then, for economic growth, the government needs to put more efforts to provide efficient public transportation facilities. For population growth, the government needs to socialize the people about the significance of small and efficient families.

2. For controlling the growth of private vehicles the regulation to limit the economic usage of cars is untill 10 yeras. The Policy to make limitation is expected to reduce the number of vehicles which are responsible for the traffic congestion.

\section{References:}

[1] Mahmud, K., Gope, K., Chowdhury, S. M. R12, Journal of Management and Sustainability, Vol.2, No.2, 2012, pp. 19254733

[7] Baxter, R. E., Davis, D, A Dictionary of Economics. Penguin Books Ltd, 20004

[5] Birge, J. R., Louveaux, F, Introduction to Stochastic Programming. Springer Verlag, 2007

[2] Jain, V., Sharma, A., Subramanian, L, Road Traffic Congestion in the Developing World. In TRB 91st Annual Meeting, Washington D.C.
[8] Kall, P., Wallace, S. W, Stochastic Programming $\left(2^{\text {nd }} e d\right)$. New York: Jhon Wiley and Sons, 2003.

[4] Levy, I.J., Buonocore, J. J., Stackelberg, V. K, Evaluation of The Public Health Impacts of Traffic Congestion: A Health Risk Assessment. Environmental Health, Vol.9, No.65.

[9] Powell, W. B., Topaloglu, H, Stochastic Programming In Transportation and Logistic, Handbook of Operation Research and Management Science, Vol. 10, 2010, pp. 555626.

[3] Rao, A. M., Rao, R. K, Measuring Urban Traffic Congestion - A Review. International Journal for Traffic and Transport Engineering, Vol.2, No.4, 2012, pp. $286-305$

\section{Creative Commons Attribution License 4.0 (Attribution 4.0 International, CC BY 4.0)}

This article is published under the terms of the Creative Commons Attribution License 4.0 https://creativecommons.org/licenses/by/4.0/deed.en US 